\title{
Aquaculture promotion through Agricultural Technology Management Agency - a case study in Kerala
}

\author{
NISHA ELIZABETH JOSHUA AND S. N. OJHA \\ ICAR-Central Institute of Fisheries Education, Panch Marg, Off Yari Road, Versova, Andheri (W), Mumbai - 400 061, India \\ e-mail: nisha.joshua@gmail.com,snojha@cife.edu.in
}

\begin{abstract}
Agricultural Technology Management Agency (ATMA) is an autonomous body that has linkage with all the line departments, like Department of Fisheries (DoF), that works towards raising farmer's income and involved in formulation of suitable strategies for empowering the farmers. In this study, ATMA impact factors among fish farmers were reviewed and discussed with the local officers. The impact factors considered were the types of culture, number of species cultured, yield disposition, marketing and expenditure in fish farming. It was observed, from a sample of 225 fish farmers, that Alappuzha, Ernakulam and Kollam districts responded more towards 'type of culture' and less towards 'marketing', whereas Kottayam and Thrissur districts responded more towards marketing. Among all the impact factors, expenditure on aquaculture was found to be significantly associated with income in all the five districts. This was followed by marketing (4 districts), yield disposition (3 districts), fish species cultured ( 3 districts) and type of culture ( 2 districts). On the contrary, it was observed that ATMA support was not similarly associated with these factors, especially for yield disposition and marketing in aquaculture. Therefore, suitable strategies are recommended to strengthen the supply chain management through ATMA.
\end{abstract}

Keywords: Aquaculture, ATMA, Extension strategy, Impact factor, Marketing

\section{Introduction}

Since India's independence, several extension initiatives viz., production oriented programmes, area development initiatives, target group based service schemes and technology delivery mechanisms were implemented with the goal of agriculture and rural development. But most of these programmes failed to meet the needs as well as to utilise opportunities required for majority of the people (MANAGE, 2007). In order to tackle the different constraints as well as to meet the emerging challenges in our extension system, the Innovations in Technology Dissemination component of National Agricultural Technology Project (NATP) implemented Agricultural Technology Management Agency (ATMA) as a pilot project from 1998 to 2005 in seven states in India viz., Andhra Pradesh, Bihar, Himachal Pradesh, Jharkhand, Odisha, Maharashtra and Punjab, through four project districts in each state. The appraisal of this pilot project undertaken by Indian Institute of Management (IIM), Lucknow reported significant positive impact and remarkable achievements of institutional and operational reforms. Based on the ATMA experiences in the NATP pilot project, extension reforms were planned under the scheme 'Support to State Extension Programmes for Extension Reforms' in the form of ATMA, on 29 March, 2005 by Department of Agriculture and Cooperation, Government of India, in 252 districts all over India during the tenth five year plan (Planning Commission, 2007), which was later extended to
591 rural districts of 29 states and 2 union territories of the country (Singh and Meena, 2012).

ATMA mainly aims at technology dissemination at district level and it focuses on agricultural diversification and increase in farm income, making it more market oriented (Sulaiman and Hall, 2002; Singh et al., 2009; ICAR, 2013). ATMA is an autonomous institution that operates under the guidance of a Governing Board (GB) that determines program priorities and assesses program impacts. The project director (PD), who is the member secretary in GB also serves as chair of the ATMA Management Committee (AMC), which includes the heads of all line departments (Singh et al., 2005). ATMA supports private extension initiatives by contracting NGOs to conduct extension responsibilities in selected areas, using the farmer to farmer extension services provided by individuals or farmers organisations and forming partnerships with input providers for demonstrations and farmer training (Mark, 2007).

In Kerala, ATMA is registered under Travancore Cochin Literary Scientific Charitable Societies Act in 1955. State Agricultural Management and Extension Training Institute (SAMETI) is a state level training institute established to impart training to extension functionaries involved in the implementation of ATMA (SAMETI, 2012). Training programmes, exposure visits and demonstrations are organised for fish farmers and breeders under ATMA in 
Kerala through the State Department of Fisheries (DoF) (ATMA Kottayam, 2009; ATMA Thrissur, 2013).

Though ATMA efforts started since 2005, in Kerala it was initiated only in 2010 and hence it is proposed to do a concurrent evaluation on whether the ATMA programme has been functioning according to its stated objectives. Therefore, at this stage it is realised to conduct a study on aquacultural developmental support activities promoted through ATMA in Kerala, which can ultimately lead to development of aquaculture in the state. Although the share of inland fish production is increasing in Kerala, its contribution is only $23.5 \%$ which has led to developing culture fisheries for ensuring food security in the context of declining capture fisheries (IASRI, 2010; Ajayakumar, 2011). Kerala has vast resources for developing aquaculture with 44 rivers extending over 85,000 ha; 53 reservoirs covering 44,289 ha; 47,216 ponds/tanks in 27,625 ha; 65,213 ha of brackishwater areas; 46,129 ha of backwaters; 12,873 ha of prawn filtration fields and 1,924 ha of mangrove areas (Economic Review, 2001; Beegum, 2006; Harikumar and Rajendran, 2007; KFS, 2011). Based on these reasons, Kerala State was selected as the study area.

\section{Materials and methods}

Since ATMA and aquaculture extension are emerging concepts in Kerala, it was assumed that ATMA might have initiated its work in the field of aquaculture in those districts dominated with fish farmers. Accordingly, the top five districts, which had the highest number of fish farmers, were purposively selected. Thus, the study was conducted among 225 randomly selected fish farmers engaged in freshwater or brackishwater fish culture in five selected districts of Kerala, viz., Alappuzha, Ernakulam, Kollam, Kottayam and Thrissur that were perceived to perform better in fish farming by the DoF and ATMA staff of Kerala. Inland fish farmer population was the highest in Ernakulam District (28\%) followed by Alappuzha (27.1\%), Kollam (14.9\%), Kottayam (10.9\%) and Thrissur (8.7\%) (Harikumar and Rajendran, 2007; DoF, 2010).

Primary data collection was done by structured interview schedule among the selected fish farmers. Factors like 'type of fish culture', 'fish species cultured', 'yield disposition', 'marketing in aquaculture' and 'expenditure in aquaculture' were found to be significantly associated with income generation from aquaculture practices, and hence these factors were chosen as 'ATMA impact factors'. The term 'ATMA impact factors' refer to those factors through which ATMA could create an impact on income of fish farmers. Besides the significant association, sufficient proof for selecting those factors as impact factors from internet (from district-wise ATMA websites) and newspaper was also collected. Under 'Type of fish culture' practiced by the fish farmer, monoculture was more risky compared to polyculture due to problems like disease outbreak and fluctuations in market price . Accordingly those who practiced both got the highest score (score: Monoculture - 1; Polyculture - 2; Both - 3). Under number of 'fish species cultured', it was perceived that more the number of species cultured, more would be the income gained (score: Each species - 1). 'Yield disposition' was assumed as consumption of fish by the family or disposal of yield, it was scored accordingly (score: Used for family consumption - 1, Sold in the market - 2, Both - 3). Government of Kerala had appointed coordinators do help mostly in marketing and 'Marketing in aquaculture' was scored as follows: (score: Word of mouth - 1, Using sign boards - 2, Advertising in gatherings, festivals, leaflets - 3, Through coordinators - 4). 'Expenditure in aquaculture' incurred per year was considered as expenditure incurred in adoption of technology (score; < ₹12,000 - 1; ₹12,00-60,0002; ₹60,001 - 1,20,000 - 3; >₹1,20,000 - 4). Associated factors taken for this study were income from aquaculture and ATMA support in aquaculture as it was assumed that ATMA support in aquaculture could enhance the income of farmers. Income from aquaculture per year was assumed to be an important factor to be associated (score: <₹12,000 - 1, ₹12,001-60,000 2; ₹60,001- 1,20,000 - 3; ₹1,20,000 - 4). 'ATMA support in aquaculture' was provided in the form of training, demonstration, exposure visit, farmer scientist interaction, rewards and incentives, innovative activities and mobilisation of fish farmer groups. The score was given on the basis of awareness about the specific ATMA supported activity, the number of days spent in that and level of satisfaction for that activity (score: Awareness about the activity - 1, Each day spent for the activity - 1, Level of satisfaction after attending the activity - Highly satisfied - 5, Satisfied - 4, Unsatisfied - 3, Highly unsatisfied - 2, No comments - 1). Spearman correlation coefficient was used to establish relationships between the variables.

\section{Results and discussion}

Table 1 enables to understand how ATMA impact factors were associated with fish farmers income in selected districts, as the primary concern of ATMA is to raise the income level of farmers by introducing production, marketing and organisational interventions and strategies.

It was observed that income from aquaculture was significantly associated with 'expenditure in aquaculture' in all the districts. After the factor 'expenditure', it was 'marketing' that was found to be significantly associated with income from aquaculture in four districts. This was followed by 'yield disposition', 'number of species cultured' and 'type of culture'. This portrays that marketing related factors are more important than production related factors for raising the income level of the fish farmers. 
Table 1. Spearman correlation coefficient between 'ATMA impact factors' and fish farmers' income

\begin{tabular}{llllll}
\hline ATMA impact factors & Alappuzha & Ernakulam & Kollam & Kottayam & Thrissur \\
\hline Type of fish culture & 0.150 & 0.271 & ${ }^{*} 0.345$ & -0.236 & ${ }^{*} 0.362$ \\
& $(0.326)$ & $(0.072)$ & $(0.020)$ & $(0.118)$ & $(0.015)$ \\
Fish species cultured & ${ }^{* *} 0.805$ & ${ }^{* *} 0.446$ & $* * 0.451$ & -0.074 & 0.187 \\
& $(0.000)$ & $(0.002)$ & $(0.002)$ & $(0.628)$ & $(0.218)$ \\
Yield disposition & ${ }^{* *} 0.398$ & 0.061 & ${ }^{* *} 0.398$ & ${ }^{*}-0.296$ & ${ }^{*} 0.366$ \\
& $(0.007)$ & $(0.691)$ & $(0.007)$ & $(0.048)$ & $(0.013)$ \\
Marketing in aquaculture & 0.175 & ${ }^{* *} 0.839$ & ${ }^{* *} 0.858$ & ${ }^{* *} 0.671$ & ${ }^{* *} 0.789$ \\
& $(0.250)$ & $(0.000)$ & $(0.000)$ & $(0.000)$ & $(0.000)$ \\
Expenditure in aquaculture & ${ }^{*} 0.501$ & ${ }^{* *} 0.926$ & ${ }^{* *} 0.898$ & ${ }^{* *} 0.844$ & $(0.000)$ \\
& $(0.000)$ & $(0.000)$ & $(0.000)$ & $(0.000)$ & $(0.000)$ \\
ATMA support in aquaculture & 0.133 & ${ }^{* *} 0.460$ & ${ }^{* *} 0.468$ & 0.180 & 0.249 \\
& $(0.384)$ & $(0.001)$ & $(0.001)$ & $(0.237)$ & $(0.099)$ \\
\hline
\end{tabular}

${ }^{* *}$ Correlation is significant at 0.01 level (2-tailed), ${ }^{*}$ Correlation is significant at 0.05 level (2-tailed) (Figures in parenthesis indicate p value)

Expenditure refers to the magnitude of household consumption which in turn depends on the income. Fish culture can increase the household income by means of its sale and can reduce the household expenditure on fish (Shrestha and Panth, 2012). Adequate extension support should be provided by DoF staff on improved culture practices. Study by Foroque (2007) in Bangladesh found that aquaculture production and marketing can have significant impact in improving the rural farmers livelihood and could lead to growth in aquaculture sector. Therefore marketing needs are to be encouraged by adequately developing infrastructural facilities either by Government or private agencies, which can be efficiently done by ATMA through its linkages with partnership organisations. When SHG members were trained by ATMA officials, they gained more confidence in planning as well as marketing (Sajesh, 2013) and hence more of such training activities are to be promoted for addressing the issues related to marketing. Yield disposition refers to the way in which the yield is utilised by farmers, that is, for own consumption or for the sales. Income from fish farming through sales is more important than self consumption, as studied by L'Heureux (1992). Therefore fish farmers need to be enlightened with the benefits like increase in income if involved in sale of their fish harvest, rather than wholly consuming it. Fish farming contributes to $15.4-86.6 \%$ of household income of farmers according to a study done by Rahman et al. (2011). Increased fish culture practices and yield can play an important role in augmenting rural development as it can provide quality food, high and diversified income thereby improving the quality of life of small scale farmers (Duc, 2008). Goswami et al. (2010) reported that annual income has positive significant correlation with scientific fish culture practices. This implies the significance of engaging in fish culture activities and employing scientific fish culture practices. Government support is essential for farmers with respect to financial and infrastructural adequacies, so that they can engage in aquacultural activities successfully, in order to raise their income (Lehane, 2013).

\section{ATMA support in aquaculture}

Relation between 'ATMA impact factors' and 'support provided to farmers by ATMA' was found out using Spearman's correlation coefficient. This relation will further give an insight into whether the 'Supports extended by ATMA' are in line with the 'Impact factors' relationships with farmers' income'. Table 2 below displays the correlation between 'ATMA impact factors' and 'ATMA support in aquaculture'.

Marketing and expenditure associated with aquacultural practices were found to be significantly correlated with ATMA support in 3 districts. Fish species cultured and income from aquaculture were significantly correlated with ATMA support in 2 districts, whereas type of fish culture and yield disposition were significantly correlated with ATMA support only in one district.

It was observed that ATMA supports all aspects related to fish farmers but it did not address areas like marketing of fish. It was seen that though the expenditure in fisheries was significantly associated with the income of the fish farmers in all the five districts, it was significantly associated with ATMA support in only three districts. ATMA support to marketing was found to be significantly associated only with three districts, though marketing was observed to be significantly associated with income in four districts. Similar gaps were observed with respect to factors like number of fish species cultured and types of farming.

Considering the gaps in marketing and extension approaches for increasing production, five strategies are proposed. The first strategy is to bring together marketing agents, producers, input sources, farmer interest groups and extension agents through workshops and trainings so that the gap existing among the fish farmers, marketing agents and other stakeholders can be minimised. Through such 
Table 2. Spearman correlation coefficient between 'ATMA impact factors' and 'ATMA support in aquaculture'

\begin{tabular}{llllll}
\hline ATMA impact factors & Alappuzha & Ernakulam & Kollam & Kottayam & Thrissur \\
\hline Type of fish culture & ${ }^{*} 0.307$ & 0.063 & 0.160 & 0.279 & 0.151 \\
& $(0.041)$ & $(0.682)$ & $(0.295)$ & $(0.063)$ & $(0.321)$ \\
Fish species cultured & 0.173 & ${ }^{* *} 0.443$ & 0.109 & ${ }^{* *} 0.319$ & 0.103 \\
& $(0.256)$ & $(0.020)$ & $(0.475)$ & $(0.032)$ & $(0.499)$ \\
Yield disposition & ${ }^{* *} 0.498$ & 0.235 & 0.156 & 0.012 & 0.233 \\
& $(0.000)$ & $(0.120)$ & $(0.308)$ & $(0.937)$ & $(0.124)$ \\
Marketing in aquaculture & 0.097 & $*^{* *} 0.635$ & 0.234 & $* * 0.493$ & $*^{* *} 0.386$ \\
Expenditure in aquaculture & $(0.527)$ & $(0.000)$ & $(0.122)$ & $(0.001)$ & $(0.009)$ \\
Income from aquaculture & $(0.374$ & ${ }^{* *} 0.396$ & 0.211 & ${ }^{*} 0.357$ & 0.187 \\
& $(0.011)$ & $(0.007)$ & $(0.164)$ & $(0.016)$ & $(0.219)$ \\
& 0.133 & $*^{* *} 0.460$ & 0.180 & $* 0.468$ & 0.249
\end{tabular}

**Correlation is significant at 0.01 level (2-tailed), ${ }^{*}$ Correlation is significant at 0.05 level (2-tailed) (Figures in parenthesis indicate $\mathrm{p}$ value)

interactions, Commodity Interest Groups (CIGs) can also be organised and such contacts with wholesalers and retailers will help the agriclinics and agribusiness centres to grow. The second strategy is to organise more number of exposure visits of the fish farmers to retailers for increasing marketing of fish. A subject matter specialist (SMS) on marketing can be identified in each district to implement the above two strategies. A third strategy is to intimate SMS on types of fish culture and species preferred by the farmer. Fourth strategy is that the department needs to have an SMS on fisheries and aquaculture extension to plan and monitor different strategies like trainings, demonstrations and exposure visits. An SMS may also be nominated to take up mass media support, like developing extension material through print, as well as, electronic media. All the nominated SMSs may be trained in the respective specialised institutions through exposure visits and may be encouraged to make presentations on their plan of action and to prepare action taken report at least once in a year to strengthen the supply chain management. Some of the SMSs may be selected under the scheme, Support to State Extension Programme for Extension Reforms (ATMA).

\section{Acknowledgements}

The authors acknowledge the support provided by Dr. W. S. Lakra, former Director and Vice-Chancellor, ICAR-CIFE and Dr. M. Krishnan, Head, Fisheries Economics, Extension and Statistics Division, ICAR-CIFE, Mumbai. Staff of ATMA and Department of Fisheries, Kerala and fish farmers of districts selected for the study are also acknowledged for providing valuable inputs for this work.

\section{References}

Ajayakumar, C. 2011. Socio-economic aspects of the development of aquaculture in Kerala. Ph. D. thesis. Faculty of Social Sciences, Department of Economics and Research Centre, Sacred Heart college, Mahatma Gandhi University, Kottayam, Kerala.
ATMA Kottayam 2009. Agriculture Technology Management Agency. Support to State Programmes for Extension Reforms. Available at http://atmakottayam.org/(Accessed 19 July 2014).

Beegum, S. S. 2006. Socio-economic condition of inland fishermen - A case study of Kerala. Ph. D. thesis. Economics Research Centre, Government College, Kottayam, Kerala.

DoA-Directorate of Agriculture 2013. Annual plan 2013-14 for support to extension work plan based on revised SREP. Circular DoA, Trivandrum, Dated 26/7/2013, ATMA.

DoF-Department of Fisheries 2010. Kerala inland fisheries statistics. Government of Kerala. Thiruvananthapuram. [Online]. Available at http://www.fisheries.kerala.gov.in/ (Accessed 19 July 2014).

Duc, N. M. 2008. Economic contribution of fish culture to farm income in South-east Vietnam. Aquac. Int., DOI: 10.1007/ s10499-008-9176-8 Available at http://www.springerlink.com.

Economic Review 2001. Kerala state planning board. Government of Kerala, Trivandrum, $65 \mathrm{pp}$.

Faruque, G. 2007. An exploration of impacts of aquaculture production and marketing on rural livelihoods in three regions in Bangladesh. Ph.D. thesis, Institute of Aquaculture, University of Stirling, Scotland.

Goswami, B., Ziauddin, G. and Datta, S. N. 2010. Adoption behaviour of fish farmers in relation to scientific fish culture practices in West Bengal. Indian Res. J. Ext. Edu., 10(1): 24-28.

Harikumar, G. and Rajendran, G. 2007. An overview of Kerala fisheries with particular emphasis on aquaculture. IFP Souvenir [Online]. Available at http://ifpkochi.nic.in (Accessed 15 July 2014).

IASRI-Indian Agricultural Statistical Research Institute 2010. Details of shrimp and scampi production during $2009-10$ [Online]. Available at http://iasri.res.in (Accessed 17 July 2014).

ICAR-Indian Council for Agricultural Research 2010. State-wise list of ATMA districts. Updated by ICAR, Zonal Project 
Directorate (Zone-III), NE Region [Online]. Available at http://www.icarzcu3.gov.in (Accessed 2 July 2014).

ICAR-Indian Council for Agricultural Research 2013. Zonal Project Directorate (Zone-III), NE Region. Available at http:// icarzcu3.gov.in (Accessed 2 July 2014).

KFS-Kerala Fisheries Statistics 2011. Kerala fisheries statistics at a glance-2011. Government of Kerala. Directorate of Fisheries. Thiruvananthapuram. [Online]. Available at http://www. fisheries.kerala.gov.in (Accessed 15 July 2014).

L'Heureux, R. 1992. Cost-benefit analysis of individual fish farms and fry production centers. FAO Corporate Document Repository, Rome Italy, 40 pp.

Lehane, S. 2013. Fish for the future: Aquaculture and food security. Strategic analysis paper-Independent strategic analysis of Australia's global interests. Available at http://www. futuredirections.org.au (Accessed 6 September 2015).

MANAGE-National Institute of Agricultural Extension Management 2007. Agricultural extension approach for XI Five year plan. [Online]. Available at http://www.manage.gov.in/ (Accessed 17 April 2013).

Mark, A. D. 2007. Unleashing India's innovation: toward sustainable and inclusive growth. International Bank for Reconstruction and Development/World Bank. http://books. google.co.in/books.

Planning Commission 2007. Recommendations of working group on agricultural extension for formulation of eleventh five-year plan (2007-12) by Working group on agricultural extension constituted by Planning Commission, Govt. of India. [Online]. Available at http://planningcommission.nic.in/ (Accessed 17 April 2013)

Rahman, S. M. A. and Haque, A. 2011. Impact of fish farming on household income: A case study from Mymensingh District. J. Soc. Sci. 7(2): 127-131.
Sajesh, V. K. 2013. Factors discriminating the effectiveness of women's joint liability groups in agriculture: evidences from Kerala. Indian Res. J. Ext. Edu., 13(3). Available at http:// www.seea.org.in/vol13-3-2013/20.pdf. (Accessed 17 April 2013).

SAMETI - State Agricultural Management and Extension Training Institute 2012. Department of Agriculture. Government of Kerala. Available at http://sametikerala.com (Accessed 17 April 2013).

Shrestha, M. K. and Pant, J. 2012. Proceedings 2012-15. Smallscale aquaculture for rural livelihoods: Proceedings of the Symposium on Small-scale aquaculture for increasing resilience of rural livelihoods in Nepal, 5-6 February 2009, Kathmandu, Nepal. Institute of Agriculture and Animal Science. Chitwan, Nepal and The World Fish Centre, Penang, Malaysia. 189 pp.

Singh, J. P., Swanson, B. E. and Singh K. M. 2005. Developing a decentralised, market-driven extension system in India: The ATMA Model. Good Practice Paper prepared for the World Bank, Washington, D.C.

Singh, K. M. and Meena, M. S. 2012. Agricultural innovations in India - Experiences of ATMA Model. Available at http:// dx.doi.org/ (Accessed 17 April 2013).

Singh, K. M., Meena, M. S., Singh, R. K. P., Kumar, A. and Kumar, U. 2009. Agricultural Technology Management Agency (ATMA): A Study of its Impact in pilot districts in Bihar, India. MPRA Paper No.45549. Available at http://mpra. ub.uni-muenchen.de/45549/ (Accessed 17 April 2013).

Sulaiman, V. R and Hall, A. 2002. Beyond technology dissemination: Can Indian agricultural extension re-invent itself. Policy brief 16. National centre for Agricultural Economics and Policy (NCAP), New Delhi.

Date of Receipt ： 09.11.2013

Date of Acceptance : 27.07 .2016 